\title{
Kesenian Indang: Kontinuitas dan Perubahan
}

\author{
Nurmalena, Sri Rustiyanti \\ Institut Seni Indonesia (ISI) Padang Panjang \\ Jl. Bundo Kanduang No. 35. Padang Panjang
}

\begin{abstract}
The art of indang, living in the community of Padang Pariaman, is a form of arts and cultural studies related to the phenomenon of continuity and change. The art of indang in the Pariaman community is still not only continuing, but also changing according to the era. The research uses qualitative method base on ethnograph approach. The result of the research aim to explain the continuity of indang which lies on the form of presentation, time and venue. The continuity is supported by internal factors, namely inheritance and cultural preservation, and external factors such as politics of identity. On the other hand, the factor of change is caused by internal factors, namely market preference, economics, educational factor, and external factor which is caused by media technology factor.
\end{abstract}

Keywords: indang, continuitas, change, Sintuak Pariaman

\begin{abstract}
ABSTRAK
Kesenian indang yang hidup di tengah masyarakat Padang Pariaman, merupakan kajian seni dan budaya yang berkaitan dengan fenomena kontinuitas dan perubahan. Kesenian indang pada masyarakat Pariaman di samping berlanjut, ia juga berubah sesuai tuntutan zaman. Penelitian ini menggunakan metode kualitatif dengan pendekatan etnografi. Hasil penelitian untuk menjelaskan kontinuitas kesenian indang yang terdapat pada bentuk penyajian, waktu pertunjukan, dan tempat pertunjukan. Kontinuitas tersebut ditunjang oleh faktor internal seperti, pewarisan dan pelestarian budaya, dan faktor eksternal seperti politik identitas. Sedangkan faktor perubahan disebabkan oleh karena faktor internal seperti, selera pasar, ekonomi, faktor pendidikan, dan faktor eksternal disebabkan oleh faktor teknologi media.
\end{abstract}

\section{PENDAHULUAN}

Di Pariaman hidup kesenian indang yang sampai saat ini eksis sebagai kesenian tradisional bernuansa islami yang dibina oleh pakar-pakar indang (wawancara dengan Pian, 23 Maret 2011). Menurut sejarahnya, kesenian indang sebagai seni tradisi awalnya berfungsi sebagai media komunikasi dalam menyampaikan ajaran Islam, kemudian berubah sebagai media silahturahmi dalam masyarakat. Selanjutnya kesenian indang berubah sebagai media hiburan, yakni hiburan pada acara pesta perkawinan, perpisahasan, dan sebagainya (wawancara dengan Ali Jastar, 10 Januari 2011).

Kata indang secara etimologis berarti "nyiru" atau alat penampi beras (Kamus Besar Bahasa Indonesia, 1995: 376). Dapat dikatakan ada hubungaan asosiatif antara kata indang dengan pertunjukannya, karena kata indang atau me-indang beras (baca: menampi) juga menyeleksi kata-kata kiasan lawan sedemikian rupa, sehingga masing-masing tim yang saling berhadap- 
an tidak kecolongan. Di sisi lain, bisa juga kata indang diberikan karena gerakan para pemain selalu menggerakkan lengan kiri ataupun lengan kanan ke arah kiri dan ke arah kanan seperti orang me-indang beras yang dilakukan sambil bersila.

Kesenian indang merupakan ragam kesenian khas milik masyarakat pantai atau pesisir Sumatera Barat (Navis, 1986: 264) Menurut Pian tukang dikie di daerah Sintuak Toboh Gadang, munculnya kesenian indang bersamaan dengan pengembangan agama Islam di Minangkabau, khususnya di Pariaman. Berdasarkan hal tersebut, kesenian indang digunakan sebagai sarana pengembangan ajaran agama Islam oleh ulama-ulama dan guru-guru agama di Surau, sehingga masyarakat menganggapnya sebagai kesenian surau (Asril, 1997: 40). Dalam pertumbuhannya, kesenian indang yang berawal dari lingkungan Surau kemudian dihidupkan oleh kelompok indang dari masing-masing nagari, dan sampai saat ini tiap-tiap nagari di Pariaman memiliki grup kesenian indang. Keberlanjutan kesenian indang berperan membawa misi tertentu, seperti hal-hal yang berkaitan dengan urusan duniawi sebagaimana pertunjukan indang pada tanggal 20 Maret 2009 di Sungai Sariek yang membawa misi tentang partai politik (Yusfil dan Asnimar, 2009: 10).

Dalam perubahannya saat ini kesenian indang dapat tampil dengan versinya masing-masing yang diringi oleh musik eksternal, bahkan dapat hidup berdampingan dengan organ tunggal yang menampilkan penyanyi wanita remaja dengan melakukan gerak-gerak secara erotis. Penyanyi bernyanyi sambil meliuk-liukkan badan dengan menggunakan kostum ketat, baju tanpa lengan dan pakai rok mini. Hal ini merupakan gejala komodifikasi yang tujuannya adalah untuk memenuhi selera konsumen (pasar). Komodifikasi oleh fairlough sebagaimana dikutip Ivan dipahami sebagai proses produksi komoditas yang tidak terbatas pada lingkup ekonomi yang sempit, yaitu hanya pada persoalan penjualan barang-barang kebutuhan, tetapi mengacu kepada pengorganisasian dan konseptualisasi pada produksi, distribusi, dan ekonomi komoditas (Ivan Robert, 2010: 35-36).

\section{METODE}

Metode penelitian yang digunakan adalah metode kualitatif, dengan pendekatan etnografi. Metode tersebut digunakan karena penulis ingin mencoba memahami dan merumuskan solusi berdasarkan hasil penelitian yang dilakukan secara langsung di lapangan. Pendekatan etnografi digunakan sebagai cara dan panduan penulis dalam melakukan penelitian di lapangan, terutama dalam mendeskripsikan kondisi lapangan, menganalisis data, dan membuat rumusan serta simpulan dari hasil penelitian yang dilakukan.

Perolehan data dilakukan oleh penulis dengan cara observasi partisipasi, wawancara mendalam dan kajian literatur yang relevan dengan penelitian.

\section{HASIL DAN PEMBAHASAN}

\section{Kontinuitas Kesenian Indang}

Kontinuitas merupakan situasi yang diharapkan dalam menentukan sikap untuk menetapkan 'sesuatu' dapat hidup, ditunjang oleh tindakan-tindakan dari masyarakat yang mengiginkannya tetap berlanjut. Namun, keberlanjutan 'sesuatu' itu tergantung dari sejarah dan latar belakang lingkungan yang akan menentukannya. Demikian juga halnya dengan kesenian Indang yang memiliki latar belakang sejarah cukup panjang.

Menurut sesepuh masyarakat Toboh Gadang, kesenian indang lahir dari surau 
yang secara teks tetap berlanjut tanpa mengurangi nilai yang melekat sebagai budaya bernuansa islami. Kesenian indang mencerminkan budaya bernuansa islami dari kata Bismillah ketika akan melantunkan syair pada awal pertunjukan dan diakhiri dengan Alhamdulillah. Hal demikian secara kontinuitas tetap dijaga oleh masyarakat Pariaman, sehingga kesenian indang dapat tampil dalam berbagai aktivitas masyarakat, seperti dalam acara alek nagari dan upacara batagak penghulu. Dalam hal ini, apabila ada alek nagari dan upacara batagak penghulu, pasti terapat pertunjukan kesenian indang yang dipertunjukkan dari berbagai nagari di lingkangan Pariaman, karena kesenian indang sudah menjadi milik masyarakat bernagari. Sehubungan dengan itu, Daryusti menyatakan bahwa kesenian akan tumbuh dalam suatu kelompok masyarakat dan akan tetap bertahan, apabila masyarakat merasa memilikinya (Daryusti, 2010: 26). Kontiniuitas dapat dilihat dari uraian berikut ini.

\section{Bentuk Penyajian}

Kesenian ini disajikan per kelompok antarnagari dalam bentuk dendangan, diiringi oleh alat musik rapa'i sekaligus sebagai properti yang digunakan pemain dalam penampilan. Pemain terdiri dari laki-laki saja berjumlah ganjil. Pada masa lalu perdebatan tidak jarang terjadi disertai dengan adu kekuatan ilmu kebatinan antara suatu kelompok dari nagari dan kelompok nagari lainnya, sehingga masing-masing kelompok harus dapat memperlihatkan kebolehannya dalam adu keterampilan tanya jawab (Wancara dengan Buyuang Enek, 16 April 2011). Tanya jawab tersebut, saling menjelekkan, menyindir, mencemooh, mengukur kemampuan lawan mengenai suatu bidang pengetahuan yang disampaikan melalui teks lirik yang didendangkan dengan bahasa yang kono- tatif, penuh kiasan, perumpamaan dalam dialek Pariaman.

Suasana pertunjukan benar-benar mengekspresikan suasana kelisanan yang disesuaikan dengan situasi dan kondisi acara. Para pemain saling mengadu kehebatan dalam bentuk kata berkias disusun dalam kesatuan pengucapan. Matranya tidak tunduk kepada aturan yang ketat dan bersifat formulaik. Teks tidak berpedoman pada naskah. Saat pertunjukan berlangsung, penonton akan memihak kepada grup favoritnya. Selama pertunjukan terjadi interaksi sosial, baik sesama khalayak maupun antara khalayak dan penampil.

Secara warisan budaya teks kesenian indang di masyarakat Pariaman dilakukan dengan cara duduk berbaris antarkelompok, dan membentuk segitiga sambil bersila, menggunakan properti rebana (rapa'i). Masing-masing kelompok memiliki personil dengan perannya masing-masing, seperti: tukang dikie, tuo indang, sipatuang sirah, anak indang, tukang aliah, tukang apik, tukang pangga, kukang kalang.

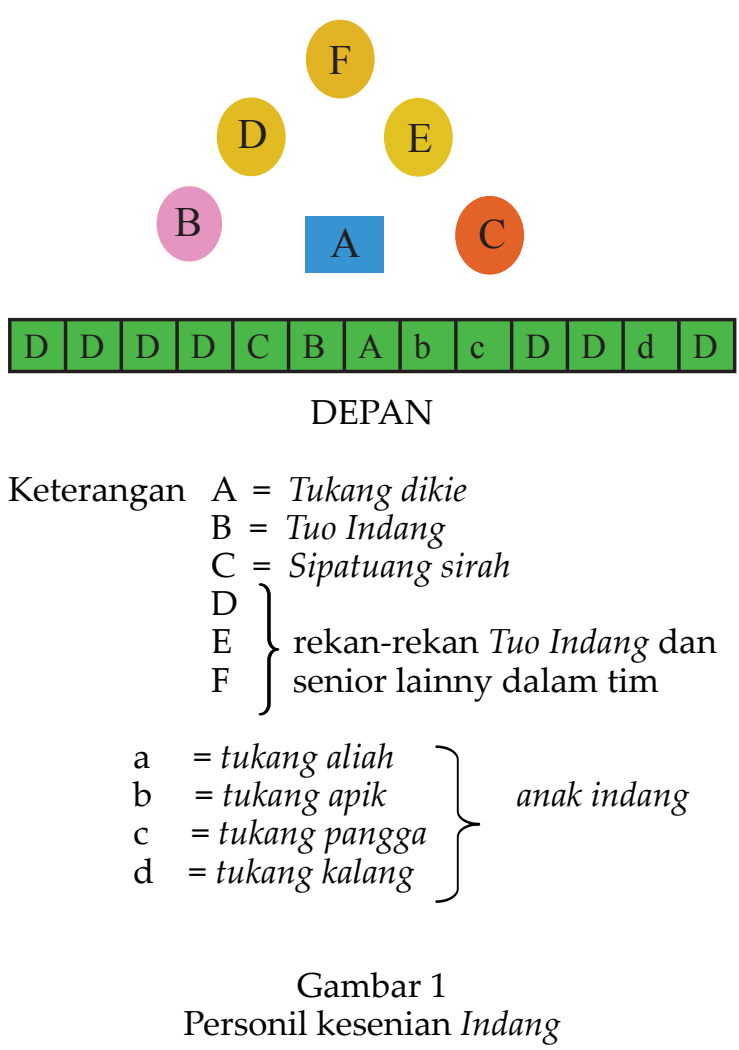




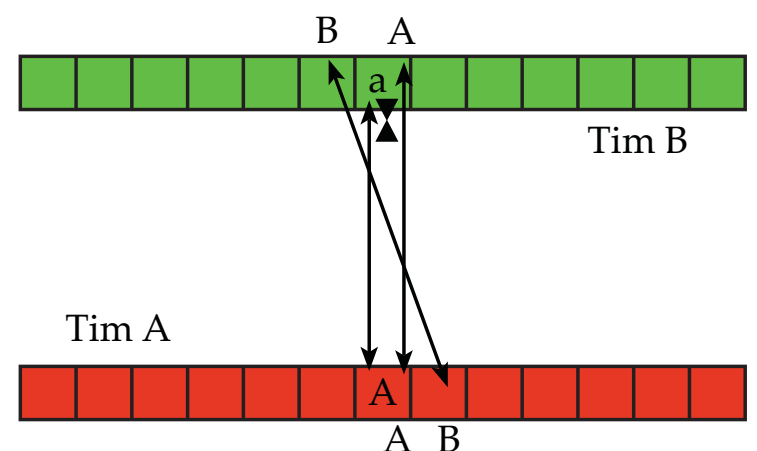

Ket: $\mathrm{A}=$ Tukang dikie

$\mathrm{B}=$ Tuo Inang

$\mathrm{a}=$ Tukang aliah

Gambar 2

Posisi Personil Inti Kesenian Indang

Hal tersebut sesuai dengan hasil analisis Margaret Kartomi tentang peran personil kesenian indang. Namun, pada personil yang dijabarkan seperti gambar di bawah ini terdapat perbedaan yang signifikan terhadap peran dari personil yang ada di tengah masyarakat Sintuak Toboh Gadang. Misalnya tukang aliah dengan tukang apik, dan tukang bunga salapan yang menggunakan huruf ' $b$ ' merupakan personil yang tingkat senioritasnya yang sama, sementara personil kesenian Indang seperti tukang aliah, tukang apik dan tukang bunga salapan yang oleh masyarakat Sintuak dikenal dengan tukang pangga dibedakan tingkat senioritasnya, oleh karena itu hurufnya dibedakan satu sama lain. Di samping itu, Tuo Indang dan Sipatuang sirah tidak dijabarkan.

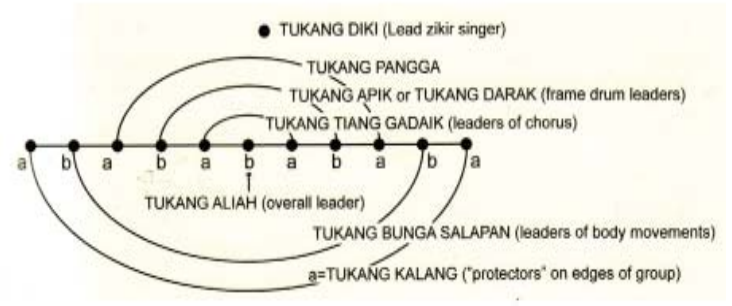

Gambar 3

Personil Kesenian Indang Sumber: Margaret Kartomi ${ }^{1}$
Bentuk penyajian tersebut berlanjut terus sampai saat ini, terutama dalam alek nagari ataupun dalam upacara pengangkatan penghulu. Secara kontinuitas, penyajian kesenian indang tersebut memiliki nilai tersendiri bagi masyarakat yang tidak akan dibiarkan punah, karena membawa ajaran tertentu yaitu Islam.

Penampilan setiap tim adalah 60 menit yang disebut sasandiang (satu sanding). Pertunjukan dibuka dengan dengan pukulan rapa'i oleh anak indang secara beramai-ramai untuk menghasilkan bunyi yang bergelombang. Setelah itu tukang dikie mulai berdendang menyampaikan nasik dan radaik.

Teks indang adalah non-cerita (tidak berisi $k a b a$ ). Isinya hanya berbagai aspek kehidupan sehari-hari masyarakatnya. Teks indang ini terbagi dua: 1) nasik, yaitu teks yang isinya nasihat yang dilandasi ajaran oleh agama Islam. Teks ini dianggap sudah baku, dan merupakan semacam pengantar dalam teks indang; 2) radaik, yaitu bagian teks yang berisikan tentang perdebatan (sindiran, menguji, mencemooh). Struktur nyanyian biasanya selalu dimulai dari $n a-$ sik baru kemudian radaik, tetapi terkadang keduanya dikombinasikan (Ediwar, 1999: 167). Teks tersebut didendangkan dengan berbagai macam irama, klasik, dangdut, irama Melayu dan irama lagu-lagu Arab atau irama lagu Padang Pasir.

Teks tersebut jelas menunjukkan awal dari penyajian kesenian indang yang dilantunkan oleh tukang dikie, berisikan ajaran agama Islam. Setelah berdendang beberapa bait, berhenti melantunkannya, disusul kemudian dengan pukulan rapa'i oleh anak indang sambil menggerak-gerakkan badannya ke kiri dan ke kanan dan menciptakan bunyi "prik" dengan cara menggesekkan ibu jari dan jari ke tengah permukaan rapa'i. Setelah bunyi rapa'i berhenti, maka tukang aliah ganti berdendang menyampaikan $r a-$ daik nya. Baris tertentu dalam bait yang didendangkan tukang aliah diulangi bersama 


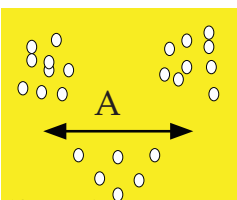

60 menit pertama
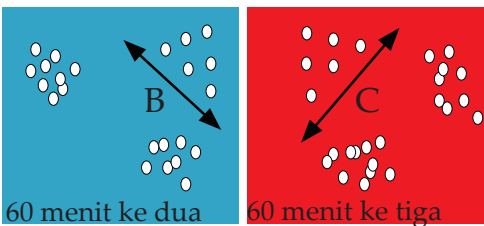

Gambar 4

Urutan penampilan kesenian Indang

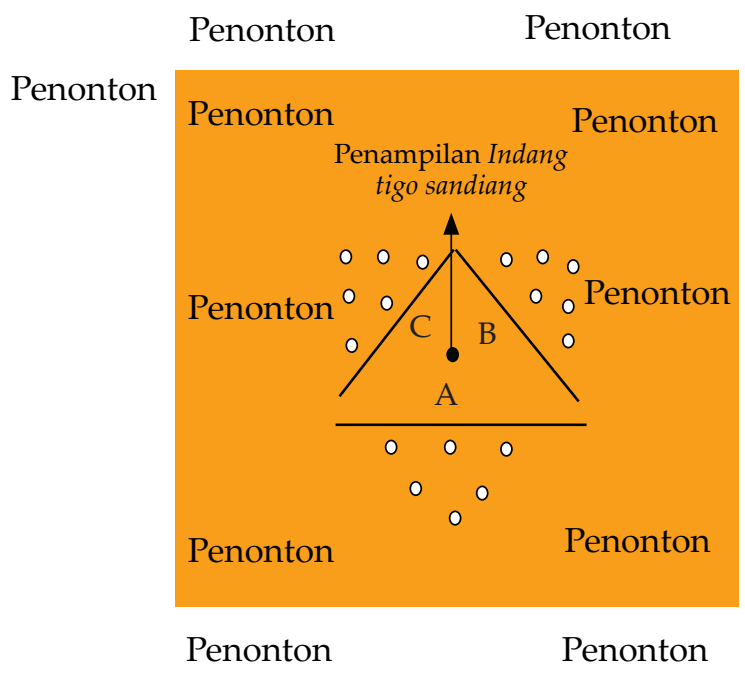

Gambar 5

Penampilan kesenian Indang tigo sandiang

oleh rekan-rekan di kiri kanannya (tukang apik, tukang pangga, dan tukang kalang). Begitu seterusnya yang dilakukan selama 60 menit, dan 60 menit berikutnya disajikan oleh kelompok kesenian indang lainnya secara bergantian, seperti terlihat struktur pertunjukannya pada gambar 4 dan gambar 5 .

\section{Tempat Pertunjukan}

Tempat pertunjukan kesenian indang di nagari Sintuak Toboh Gadang disebut lagalaga. Laga-laga adalah bangunan khusus yang ukurannya bermacam-macam sesuai dengan kebutuhan, ada yang sifatnya permanen, ada pula yang semi permanen. Biasanya laga-laga ini digunakan untuk kegiatan latihan silat atau untuk kegiatan lainnya di bidang seni, maka wilayah kegiatannya cukup diberi tonggak empat,

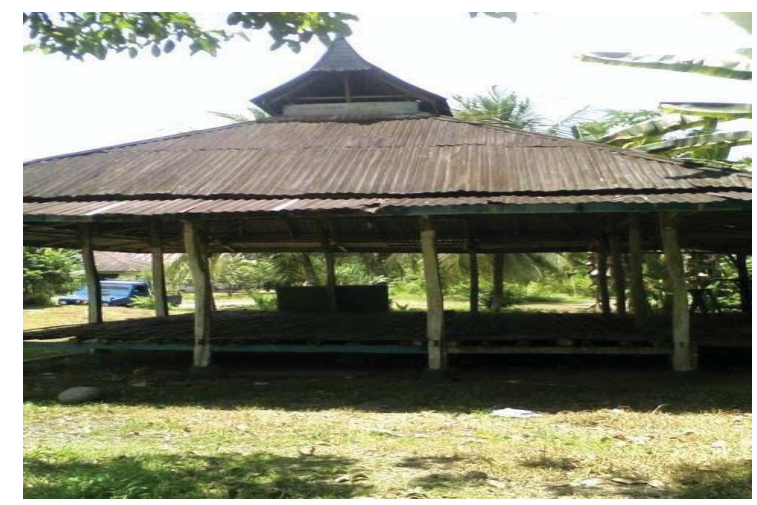

Gambar 6

Laga-laga permanen

(Dokumentasi: Nurmalena, 2011)

enam, atau delapan buah sebagai penyangga bangunan. Dengan demikian bangunannya dibuat persegi empat, kemudian diberi atap seng atau atap rumbia seperti terlihat pada gambar 6 .

Menurut Edi Sedyawati, tempat kegiatan silat ataupun tari atau bentuk-bentuk kegiatan kesenian lainnya di Minangkabau disebut sasaran yaitu suatu tempat yang tanahnya diratakan. ${ }^{2}$ Berdasarkan hal ini dapat dijelaskan bahwa tempat kegiatan silat atau kegiatan seni lainnya di Minangkabau bukan di sasaran yang tanahnya diratakan itu saja. Akan tetapi ada yang disebut laga-laga yang sangat terkenal di Pariaman.

\section{Perubahan Kesenian Indang}

Kesenian indang sebagai kesenian rakyat hidup dan dihidupkan oleh rakyat. Dalam perjalanan dan perkembangannya menuntut kreativitas dari kelompok atau pelaku kesenian indang. Oleh karena itu kesenian indang megalami perubahan dan pergeseran karena pengaruh perkembangan zaman.

Dahulu kesenian Indang tampil di surau untuk syiar agama Islam dengan pemain laki-laki dewasa. Kemudian kesenian Indang tampil di atas laga-laga dengan pemain laki-laki secara berkelompok dengan tu- 
juan adu keterampilan bersilat lidah dalam mempertahankan nagari dari masing-masing peserta. Selanjutnya berubah menjadi paket pertunjukan dengan pemain terdiri dari laki-laki dan perempuan. Tentu saja hal ini tidak lepas dari perubahan budaya dan tuntutan zaman. Sehubungan dengan hal di atas, Gillin menyatakan bahwa, perubahan merupakan:

Suatu variasi cara-cara hidup yang telah diterima, baik karena perubahanperubahan kondisi geografis, kebudayaan materiil, komposisi penduduk, ideologi maupun karena adanya difusi atau penemuan-penemuan dalam masyarakat (2011: 4).

Berdasarkan pandangan Gillin tersebut, kesenian indang memang berubah karena cara pandang masyarakat terhadap kesenian itu sendiri. Situasi pertunjukan indang yang diramaikan adu keterampilan kebatinan, dan hakikatnya profan itu menyebabkan kesenian indang dipandang agak negatif oleh kalangan tertentu dalam masyarakat. Kaum ulama misalnya menganggap kesenian indang lebih mengajak orang memikirkan dunia saja. Kondisi ini sangat berbeda dengan keadaan pada saat awal kemunculannya yang justru didukung oleh kaum ulama. Berdasarkan pandangan masyarakat, untuk menjadi anak indang adalah pekerjaan yang berbahaya, karena mungkin pada suatu saat akan mendapat celaka terkena ilmu hitam lawan. Dewasa ini kekhawatiran akan dampak negatif semakin berkurang, sejalan dengan semakin hilangnya tradisi perang ilmu hitam dalam pertunjukan.

Dengan berubahnya cara pandang masyarakat terhadap pertunjukan indang, maka kesenian indang tampil dengan berbagai bentuk, bahkan tampil dalam membawa misi politik sebagaimana pertunjukan indang yang terdapat di Sungai Sariek dalam rangka menaiki laga-laga, sekaligus mengemban misi politik tentang caleg Padang Pariaman (Yusfil \& asnimar, 2009: 3).

\section{Bentuk Penyajian}

Pertunjukan kesenian indang saat ini tidak lagi mengutamakan adu kekuatan ilmu kebatinan antara satu tim dari nagari dengan tim nagari lainnya, tetapi sudah menyesuaikan dengan situasi dan kondisi masyarakat. Kesenian indang tetap memiliki unsur keterampilan bersilat lidah untuk mempertahankan kehebatan dalam mempertahankan suasana kelisanan. Namun dengan demikian unsur hiburan lebih diutamakan dalam pertunjukannya, sehingga penonton juga merasa terhibur oleh syairsyair yang dilantunkan oleh pemain.

\section{a. Personil}

Secara tradisi personil kesenian Indang terdiri atas kaum laki-laki, minimal berusia 17 tahun dan telah paham nuansa kelisanan. Akan tetapi saat ini sudah ada yang berusia 8 tahun seperti terlihat pada gambar 7 .

Gambar 7 menunjukkan bahwa jumlah ganjil tetap dipertahankan dalam pertunjukan, demikian juga kedekatan penonton dengan pemain. Di sisi lain, jika dahulu personil kesenian indang terdiri dari tukang dikie, Tuo Indang, Sipatuang sirah, dan anak indang, sekarang Tuo Indang, dan Sipatuang sirah tidak lagi berperan dalam sebuah pertunjukan. Tukang dikie dan anak indang tetap eksis jika dipertunjukkan dalam alek nagari.

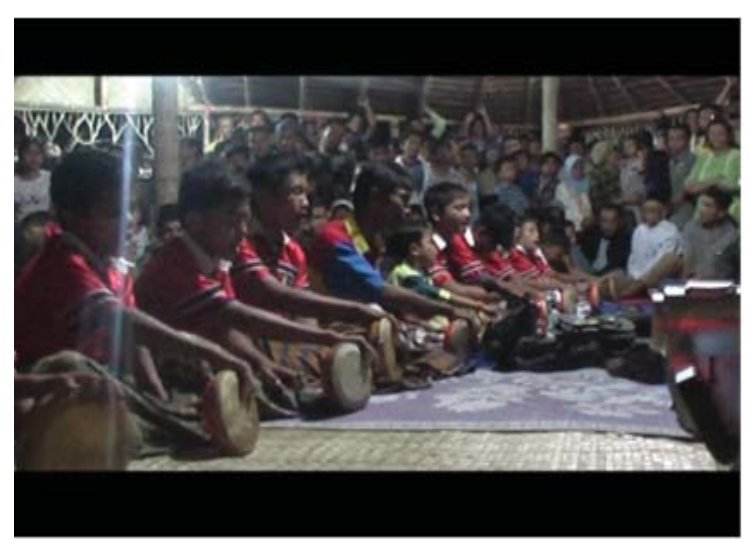

Gambar 7

Personil kesenian Indang anak-anak berusia 8 tahun dalam acara batagak gadang, Kabupaten Padang Pariaman (Dokumentasi: Nurmalena 2011) 
Di samping itu, tukang aliah, tukang apik, tukang pangga, dan tukang kalang sebagai anak indang, tidak mengalami perubahan dari segi perannya sebagaimana budaya pertunjukan tradisi.

\section{b. Tempat Pertunjukan}

Tempat pertunjukan kesenian indang bermula dari surau. Surau tempat mengaji dan berlajar ilmu agama bagi kaum lakilaki, tempat awal mulanya kesenian indang ada. Surau sebagai tempat ibadah bagi umat Islam, sekaligus dapat juga dijadikan tempat kegiatan seni yang bernuansa Islam, seperti; selawat, zikir, dan kesenian indang. Dalam perkembangannya kesenian indang berubah menjadi seni pertunjukan, sehingga tempat pertunjukannya kesenian dinamakan laga-laga.

\section{c. Bentuk Penyajian}

Apabila kesenian indang berfungsi sebagai hiburan, penampilannya tidak serumit seperti dalam kegiatan alek nagari yang terdiri atas indang naiak dan indang turun. Kesenian indang dapat tampil sesuai dengan kondisi acara. Namun suasana kelisanan tetap terjaga, terkadang sudah diiringi oleh musik eksternal untuk menambah keindahan gerak yang dilakukan pemain.

\section{PENUTUP}

Kontinuitas kesenian indang merupakan suatu keberlanjutan untuk mempertahankan eksistensinya di tengah masyarakat. Faktor kontinuitas tidak lepas dari faktor internal dan eksternal. Faktor kontinuitas kesenian indang dapat dilihat dari eksistensi kesenian indang itu sendiri dalam masyarakat.

Dalam perjalanannya, kesenian indang mengalami perubahan mengikuti dinamika perubahan masyarakat pendukungnya, perubahan yang terjadi berupa perubahan sosial dalam hal ini perubahan sosial budaya dari religius ke profan. Dalam kenyataannya kesenian indang mampu mengisi kebutuhan hiburan dalam masyarakat, seperti dalam kegiatan upacara adat, batagak gala, pesta perkawinan, dan lain sebagainya, bahkan sebagai bentuk tari, ia dapat dipelajari di sekolah-sekolah dalam mata pelajaran seni budaya di Padang Pariaman.

\section{Catatan Akhir}

${ }^{1}$ Margaret Kartomi. 2012. Musical Journeys in Sumatera .hicago: University of Illionis Press, p. 105.

${ }^{2}$ Edi Sedyawati. 1981. Pertumbuhan Seni Pertunjukan. Jakarta: Sinar Harapan. p, 72.

\section{Daftar Pustaka}

A.A Navis

1986 Alam Takambang Kadi Guru. Jakarta: PT Grafiti Pers

Asril

1997 "Seni Pertunjukan Indang Pariaman Minangkabau, Pergeseran dari Religius ke Profan" Dalam Jurnal Seni dan Budaya. No 1. Tahun 1. ASKI Padangpanjang

Daryusti

2010 Lingkaran Lokal Genius \& Pemikiran Seni Budaya. Yogyakarta: Multi Grafindo

Edi Sedyawati

1981 Pertumbuhan Seni Pertunjukan. Jakarta: Sinar Harapan

Ediwar

1999 "Perjalanan Kesenian Indang Dari Surau Ke Seni Pertunjukan Rakyat Minangkabau Di Padang Pariaman man Sumatera Barat", Tesis. Yogyakarta: Program Pascasarjana Universitas Gadjah Mada 
Gillin dalam Nanang Martono

2011 Sosiologi Perubahan Sosial. Perspektif Klasik, Modern, Posmodern, dan Post Kolonial. Jakarta: PT Radja Grafindo

Ivan Robert Bernadus Kaunang

2010 “Komodifikasi Tari Maengket Minahasa, Sulawesi Utara Di Era Globalisasi". Disertasi. Program Pascasarjana Universitas Udayana Denpasar

Kamus Besar Bahasa Indonesia

1995 Edisi kedua. Jakarta: Balai Pustaka Departemen Pendidikan dan Kebudayaan.

Margaret Kartomi

2012 Musical Journeys in Sumatera. Chicago: University of Illionis Press.
Yusfil \& Asnimar

2009 "Laporan Magang Tari Indang Pariaman". STSI Padangpanjang: Jurusan Tari

Sumber Informasi lain:

Wawancara dengan Buyuang Enek, 57 tahun, mantan pemain indang, 16 April 2011 di Sintuak Toboh Gadang.

Wawancara dengan Ali Jastar, ninik mamak, 58 tahun 10 Januari 2011 di Lubuk Alung, Kabupaten Padang

Wawancara dengan Pian, 55 tahun, di Lubuk Alung, 23 Maret 2011. 